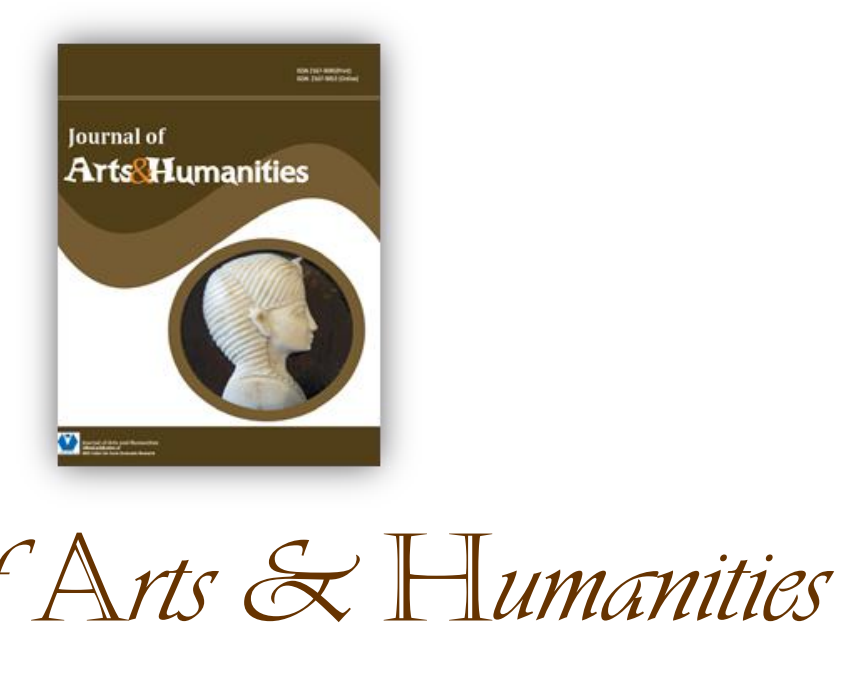

\title{
Indonesian Traditional Toys and the Development of Batik Motifs
}

\author{
Bagus Indrayana', Karju², Prima Yustana3
}

\begin{abstract}
There is a wide array of traditional toys in Indonesia. In the past, traditional toys played an important role for skill and creativity development of children. Today, the position of traditional toys in the society is displaced by toys from large-scale manufacturers. Given the critical role of traditional toys for children's motoric and social development, there is a need to develop media that can be used to promote these traditional products and strengthen their position in the public. We propose to use Batik as a way to effectively disseminate and promote traditional toys to the general public. Apart from this, using traditional toys to create new Batik motifs can have an economic value for the producers of Batik, promote Indonesian products and enrich the Indonesian Batik. This study aims to explore the variety of traditional toys, mainly from Klaten and Magelang, in the Central Java province of Indonesia, and use them as the basis for the development of Batik motif creation. This study used Trilogi Keseimbangan (or Harmony Trilogy) aesthetic theory analytical approach that explains the creation of craft consists of the following phases: exploration, design, and materialization. The creation method in this study adopts Tiga Tahap Enam Langkah (Three Phases, Six Steps) method offered in the theory. The finding in the field found that the traditional toys material used in Klaten and Magelang, mostly made from waste wood, plywood, and zinc. The manufacturing process is done manually by two or three craftsmen using a simple technology. The traditional toys are designed by the artisans mostly, although there may be designs from the clients.
\end{abstract}

\footnotetext{
${ }^{1}$ Assistant Professor, Department of Craft Arts (Kriya), Faculty of Fine Arts and Design, Indonesian Institute of Arts Surakarta. Email: bagusindrayana768@yahoo.com.

${ }^{2}$ Assistant Professor, Department of Craft Arts (Kriya), Faculty of Fine Arts and Design, Indonesian Institute of Arts Surakarta. Email: Karju88@isi-ska.ac.id.

3 Instructor, Department of Craft Arts (Kriya), Faculty of Fine Arts and Design, Indonesian Institute of Arts Surakarta. Email: pyprim@gmail.com.
} 
In addition, we also found that the traditional toys have never been used as a Batik motif. The traditional toys Batik motif presented in this work is researcher's design. For the purposes of this study, we first research the variety of traditional toys available in the market today in Indonesia. We look into the process of creating these toys. Finally, we develop our own designs with the idea that these designs can be used in the creative industries, particularly in the business of batik.

Keywords: Batik fashion, new batik motif, traditional toys.

Available Online: 25 th June, 2016.

This is an open access article under Creative Commons Attribution 4.0 License, 2016.

\subsection{Introduction}

There is a wide variety of traditional toys in Indonesia. In the province of Central Java, traditional toys take the shape of household appliances (traditional cookware, dining sets), modes of transportation (bicycle, motorbike, pedicab, car, truck, aeroplane, train, chart horse, and bus), animals (bird, duck, goose, horse and monkey). In addition, there are other toys, such as umbul wayang (wayang cards made from paper), kuda lumping (play horse that is used for a jathilan dance), paper puppets, gasing or gangsingan (a yoyo-like toy made from bamboo), ethek - ethek (wooden noise maker), dakon (mancala), and kites. These traditional toys can be classified into two-dimensional and three-dimensional toys. They can be made from clay, wood, plywood, bamboo, tin, hard sponge and paper. All materials that are used in the production of these toys are a waste material that can be obtained by crafters in the surrounding neighborhoods or in other areas close-by.

In the past, these traditional toys played an important role in children's lives. They were used for play, rest and relaxation. Apart from this, they also helped children them to make friends with each other (because they are interactive), enhance motoric skills, build discipline and honesty value, and a feeling of togetherness (Suharsimi Arikunto in Dharmamulya, 2005). Finally, by playing with these toys, children learn to appreciate a creative process of producing works of art, specifically, that of craftwork (because they are manufactured simply from readily available materials). These are all important roles the traditional toys play. In the past few decades, traditional toys started to lose their market due to the popularity of factory production toys. On the other hand, although the use of traditional toys among children is increasingly displaced by the flood of toy manufacturers, the production of traditional toys continues among traditional toy artisans. They do this either as a part-time job, a side or a main job in order to make profit or increase their daily income. One can say that there is a potentially greater production and marketing space for the works of traditional toy artisans.

Batik is a perfect medium for spreading the idea of the traditional toys because of its popularity in the Indonesian society. Guntur (2014) says that Batik products in Indonesia, especially in Java Island, had specific characters in every regions. He pointed that the differences from Batik visual aspects caused by natural environment, social and cultral background, history, technical, philoshopical and economic factors.

The development of Batik motif based on a variety of traditional toys can open new perspectives among designers, experts, and academics and, thus, contribute to the development of creative industries in the Indonesian textile industry. In addition, the traditional toys Batik motif could add more economic opportunities for Batik crafters and other stakeholders.

This study aims to identify the array of of traditional toys which can be used as Batik motifs and how to create Batik motifs based on traditional toys. We, first, map the range of traditional toys from the Klaten and Magelang region in the province of Central Java, Indonesia. And, subsequently, use the results to design new Batik motifs. The study hopes to practically contribute to the development of creative industries and add economic value to the people engaged in the Batik and the traditional toys craft business. 


\subsection{Discussion}

\section{a. Traditional Toys at Klaten region, Province of Central Java, Indonesia}

Klaten region is located in the province of Central Java and consists of several sub-districts and villages. This area is an agricultural area and majority of the population are farmers. Nevertheless, there are several villages that is populated mostly by artisans. We conducted our research in Blanciran and Bayat villages. Here, most residents worked in the field of craft business.

\section{Traditional Toys at Blanciran village, Klaten, Central Java Province}

Blanciran village has a strategic location. This village is located on the highway leading to the capital of Klaten. The village is approximately $4 \mathrm{~km}$ from the district town, Karang Anom and is approximately 9 $\mathrm{km}$ from the capital of the Klaten region. This strategic positioning allows it to distribute its production and to import raw materials from other regions of the area.

Most traditional toys businesses in Blanciran are run as a home industry. For toy materials, the craftmen use wasted wood and wood logs (glondhongan). They get those raw materials from the neighbourhoods, nearby areas or from outside the region. Most of their toy products are sold to the districts outside the city and some are taken or purchased directly by the buyer. The craftsmen in this Blanciran village make toys by hand using tools, such as cutting machines, drills, smoothing machines, finishing tools, and other machinery. This machine tools help them to speed up the production process and especially, aid them in the accuracy, precision, and quality that can meet customers' needs.

For the Blanciran villagers, making children's toys is mostly a sideline business. They become traditional toys craftmen to earn additional income while their main job remains as a farmer or a construction worker. Statistically, Blanciran village has 20 tradtional toys craftsmen that are organized in a craftsmen association called Paguyuban Karya Maju Bersatu (KMB), under the leadership of Moslem (Head I) and Sofiyan (Chairman II).

The Blaciran village tradtional toys products are very popular, mostly because their products are unique, aesthetically pleasing, and have a good quality. The Blanciran village children toys are mostly inspired by the modes of transportation, thus, they are made in the shape of bicycles, tricycles, motorcycles, cars, trains, airplanes, and others.

They use two kinds of wood. First, teak/mahogany/rosewood from the leftover furniture that is purchased at a price of Rp 100,000-150,000 per quintal. Second, wooden sticks (glondongan) purchased at a price of $\mathrm{Rp} 800,000$ per cubic meter. Both materials are obtained from the region close-by (from the Ceper and Delanggu region). The furniture-making leftover materials are commonly used to make different small-sized transportation-shaped toys. These raw materials are also used to make certain small toy parts, like wheels, shock-breakers, lamps, and mirrors. Glondongan wood (stick wood) is used to make toys that are big, long, and heavy type. For the production equipement, the Blanciran village craftsmen used appropriate machinery and equipment tools for splitting, cutting, deburring, and finishing products. They use wood glue for the assembly and melamine with an airbrush or spray technique for a finishing process.

small wood materials and wheel

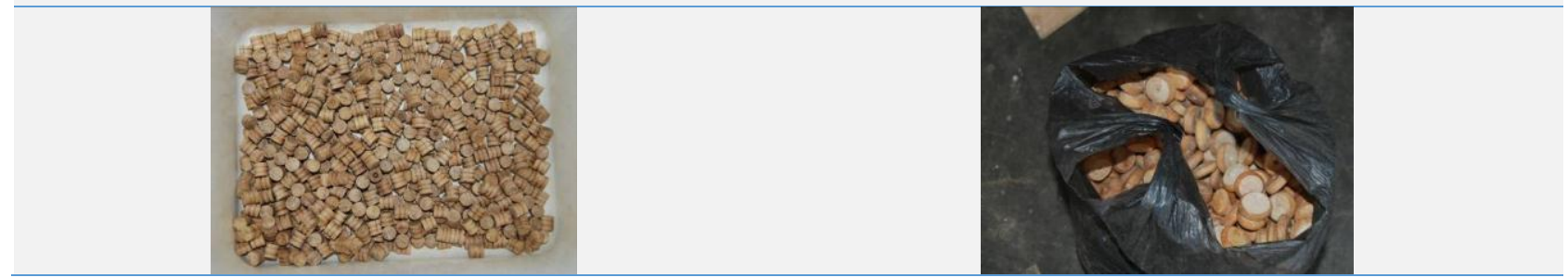




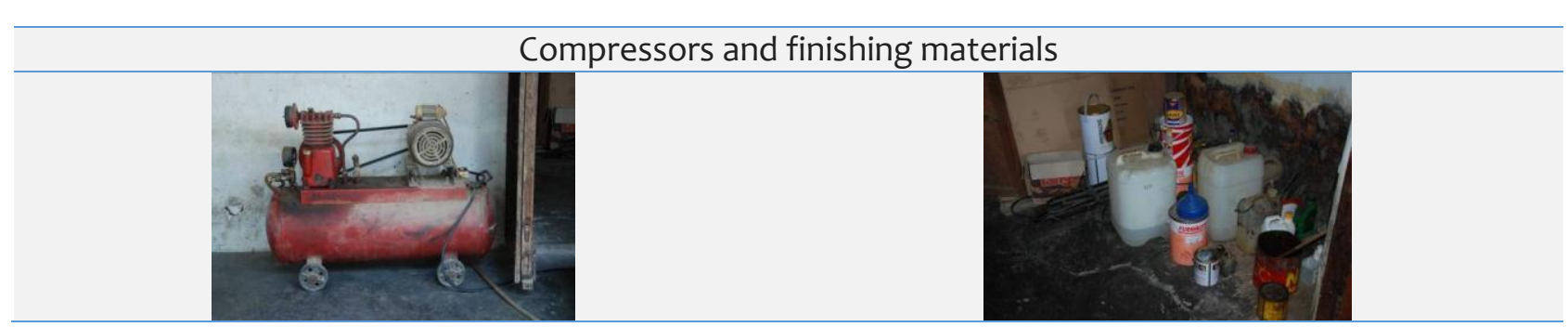

Toy design is not made by the crafters, but comes from a client, both from within and outside the country. Prices for Blanciran toy products are between Rp 10,000 to Rp 45,000 each. The Blanciran craftsmen produce approximately ten to twenty units with a system of daily wages with an overtime fee. This wage labor model force is not based on the difficulty level of production design, nor based on the educational level, rather, it depends on the willingness of craftsmen to work. Their wage is often decided by the client to make sure that the crafter makes a profit.

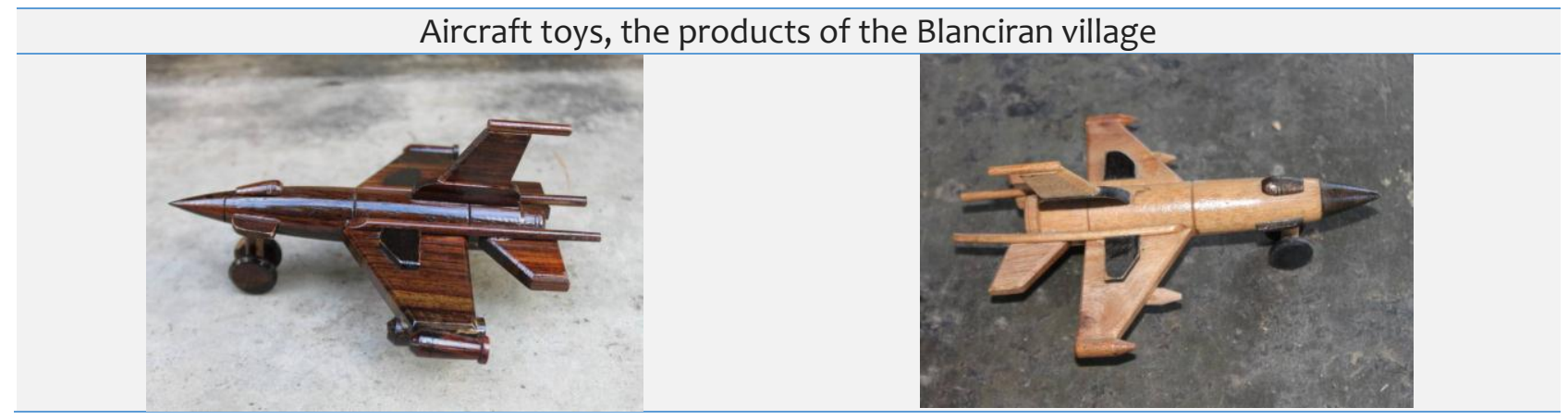

\section{Traditional Toys at Bayat Village, Klaten Centra Java Province}

Bayat has two ceramics centers, namely Pagerjurang Melikan and Pagerjurang Paseban villages. The transportation infrastructure in these villages is relatively developed to facilitate the delivery of goods production into various destinations. The ceramics bussiness in Melikan is a home-based business, that produces decorative objects, housewares, toys and various objects from clay. In general, Bayat ceramics artisans use old techniques that rely on manual skills for their production, which is massage (pinching), a helical technique, and a swivel tilt technique.

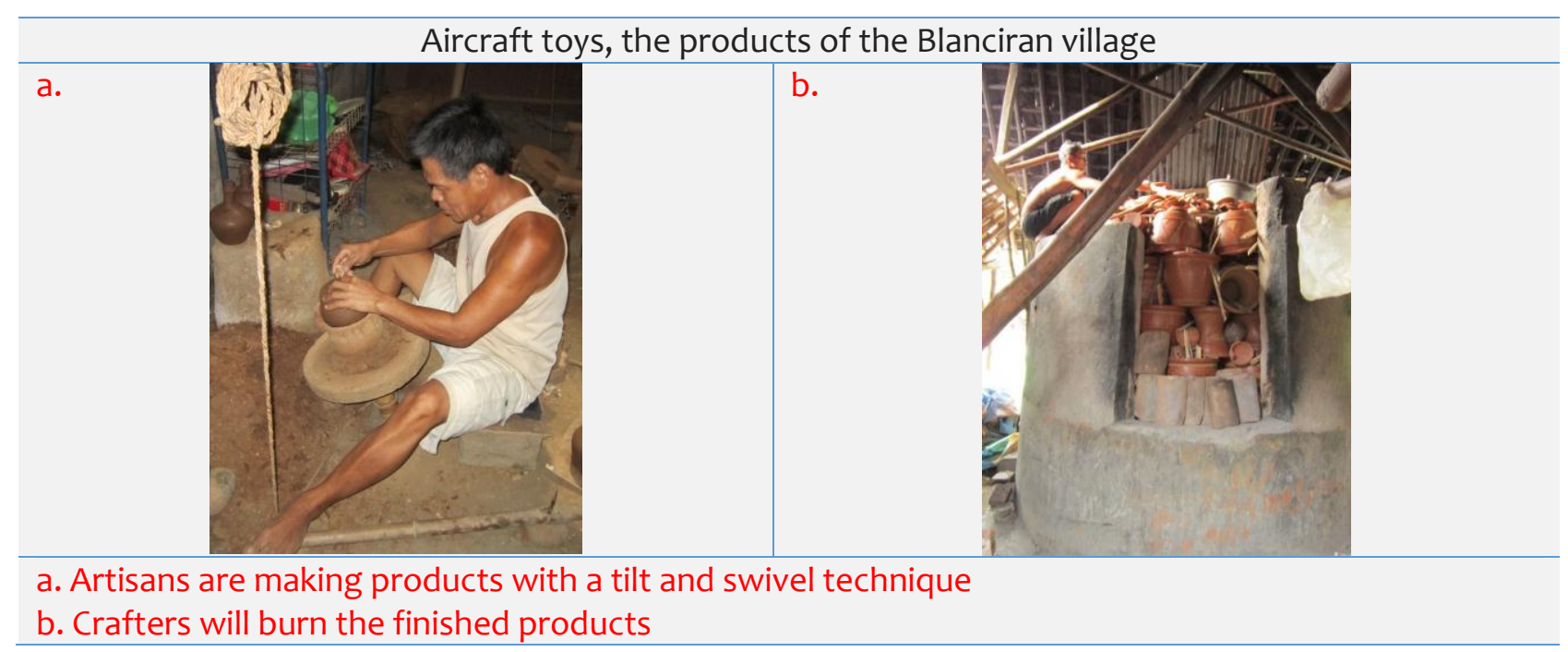

\section{B. Traditional Toys at Magelang region, Central Java Province}

1. Traditional toys at North Jurangombo village, Magelang, Jawa Tengah 
North Jurangombo is a village located at the crossroads of the two economic and tourist highway routes, Semarang - Magelang - Yogyakarta and Purworejo - Temanggung. This village is also surrounded by Merapi, Merbabu, Sindoro, Sumbing mountains and Gianti, Menoreh, Andong and Telomoyo hills (Bappeda, Magelangkota, 2013). In North Jurangombo village, there is a small hemlet that became a center of the children's toys craft industry, namely Sampangan Ngaglik hemlet. Approximately Ngaglik Sampangan acreage is 58 ha, with a population of 3,807 inhabitants (Sumarwiyanto, 2010: 21). Sampangan Ngaglik village location is quite strategic and close to the tourist attractions Kyai Langgeng. This tourist place is quite beautiful and attractive for tourists to visit and the craftmen take advantage of this geographical location to market their products.

This toy making industry in the Sampangan viillage is a home business industry. They make toys by hand, using appropriate machinery and equipment, like wood cutting machine (scroll saw) and the compressor (a finishing tool). This manufacturing of toy products is the main livelihood occupation for Sampangan villagers. As stated by an artisan, Sutrisno, this job as a toy maker is not a sideline job but is the main source of their income. Based on data obtained from Sinulingga Santoso (a craftmen and a Secretary of the Manunggal Jaya Craftmen's Association), there are thirty artisans in Sampangan, but only twenty one artisans are the members of the craft association, the Komunitas Manunggal Jaya (KMJ), chaired by Ngadiyono. The toy products in this village are inspired by the shape of land and air transport equipment and animals (horses, chicken, and ducks).

The materials used by the Sampangan Ngaglik village craftmen can be divided into two kinds. First, plywood and white wood materials. Plywood materials used to make the overall shape of the toy, be it ducks, trucks, cars, and buses. White wood comes from Sengon, Dadap and Acacia trees. White wood is only used for the manufacture of a teletubbies train, horse carriage, baby rocking horse, the baby rocking train and truck's body. Some crafters, like Sutrisno Santoso and Supardi say that all the raw material they use is from a waste material (waste) from residential buildings, offices, or other leftover building materials. These materials are obtained from the collectors, both from the neighborhood and from outside the region, such as Temanggung, Salatiga and Semarang regions. The price of plywood and wood waste for one truck is worth Rp 1.250.000-1.800.000.

Secondly, auxiliary materials are divided into two kinds, the construction reinforcement materials (nails and wood glue) and finishing materials, like putty, sandpaper, paint, and paper or mica to create object patterns/decorative motifs. The equipment that is used in toy manufacturing is wood cutting machine (scroll saw), handsaw, drill, and iron.

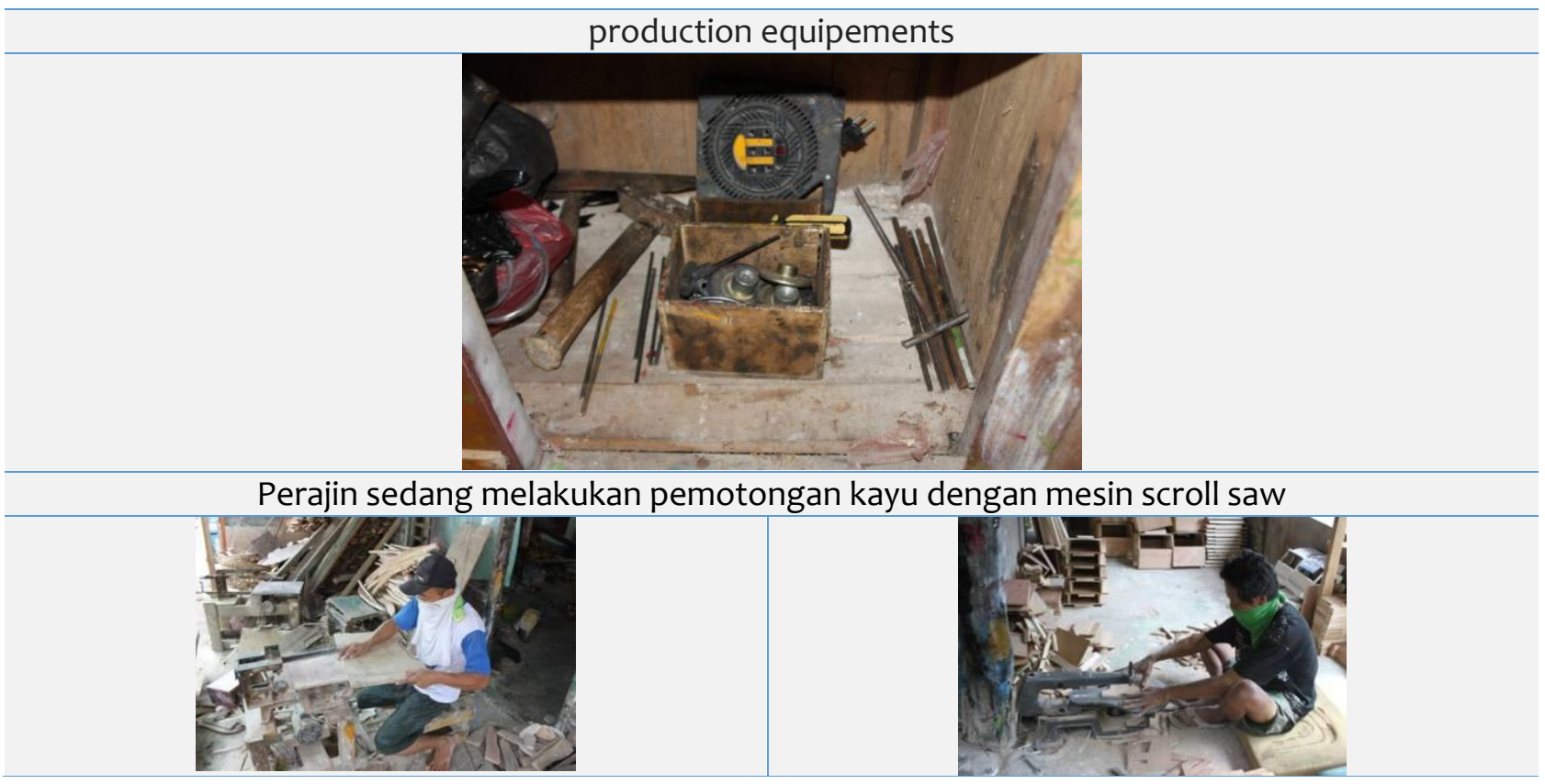


In Sampangan village, they make their own toy product design. But they order the decorations for toys (such as the drawing of tigers and others) from experts in the form of model/mold. Toy products' size is quite varied, ranging from small, medium, and large sizes. The small truck toy size: length $\mathrm{x}$ width is $40 \mathrm{~cm} \times 20 \mathrm{~cm}$, medium size equals $50 \mathrm{~cm} \times 20 \mathrm{~cm}$, while the big truck toy size is $1 \mathrm{~m} \times 40 \mathrm{~cm}$. The price of these products also varies, depending on their size. The small toy truck price is $\mathrm{Rp} 20,000, \mathrm{Rp} 40,000$ for medium-size, and large size costs $\mathrm{Rp} 300,000$. Baby rocking horse costs $\mathrm{Rp}$. 30,000-40,000, aircraft toys cost Rp 10,000, and the Teletubbies train costs Rp 12,000 to Rp 13,000. They use a contract system for their wages, with Rp 11,000 for the small size truck toy and Rp 16,000 for medium-size, plus a meal twice per day.

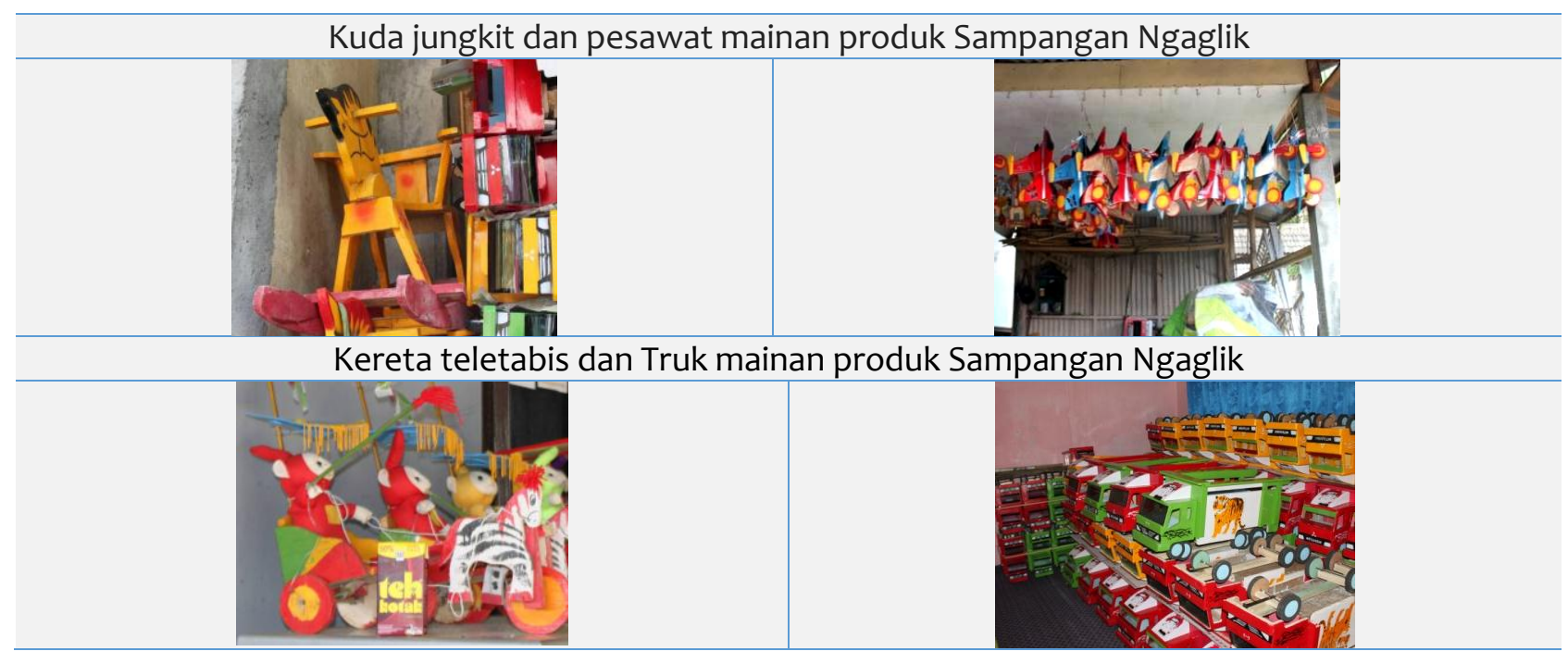

\section{Toys in Pabelan, Magelang, Central Java Province}

Pabelan region is located in the District of Mungkid, Central Java. Its area is $348.00 \mathrm{~km}^{2}$, with a population of 8,855 inhabitants (Budiarta, 2013: 20). Their location is very strategic. Close with the famous Borobudur temple. This helps them to gain their market. Here, the traditional toys industry is also a home business. In Pabelan village, there are 19 craftsmen that are organized through the Bamboo Studio Tutul craftmen association, led by Wahyudi. Like in the other crafter villages, Pabelan village crafters rely on their hand skills, with simple tools (machetes, wood knife, and handsaw) aiding them in the production of their toys.

Various toys produced by Pabelan crafters are inspired by geometric and animal shapes, like birds, ducks, and chicken. The raw material that they use is bamboo (Bambusa Vulgaris), acacia, and hard sponge (foam). The bamboo and Acacia wood is obtained from their surrounding, whereas they get the hard foam from household materials store.

\begin{tabular}{|l|l|l|}
\hline Bird Toys & Ethek-Ethek & Gangsingan \\
\hline
\end{tabular}

\section{Batif Motifs Based on Traditional Toys Development Results}

The aesthetic theory formulated by Gustami (2007) states that Tiga Tahap Enam Langkah (Three Phases Six Steps) method can be used by artisans in the process of creating crafts. We apply this method in 
creating our batik motifs. First, we reviewed literature to understand the historical aspect of the social and cultural context, and then conducted field observation to know the variety of traditional toys that can be developed as Batik motifs. Secondly, we analyzed all the results of studies and field observations to find themes and to sketch titles of an alternative form of the desired Batik motifs. Third, the sketch results were presented in a discussion forum with the research team to select and assign the best sketch to be developed in the form of a pattern, and then transferred it into textile media (calico) using a Batik technique. Fourth, the results were then evaluated together with entrepreneurs to obtain the input for further refinement. Fifth, the improved work was evaluated by connoisseurs and observers and we obtained further comments and suggestions. Sixth, the final design was presented to the relevant companies. Thus, we finalized the design of batik motifs, as shown below.

\section{Allternative development I}

\begin{tabular}{|c|c|c|c|}
\hline Clay Stove & Basic sketch & Motif Patterns & Motif Alternatif "Clay stove (anglo) Batik" \\
\hline & & 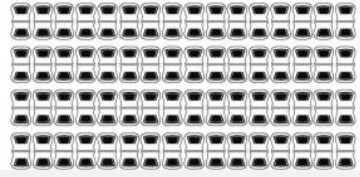 & 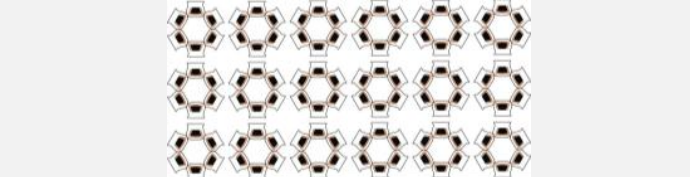 \\
\hline
\end{tabular}

\section{Allternative development II}

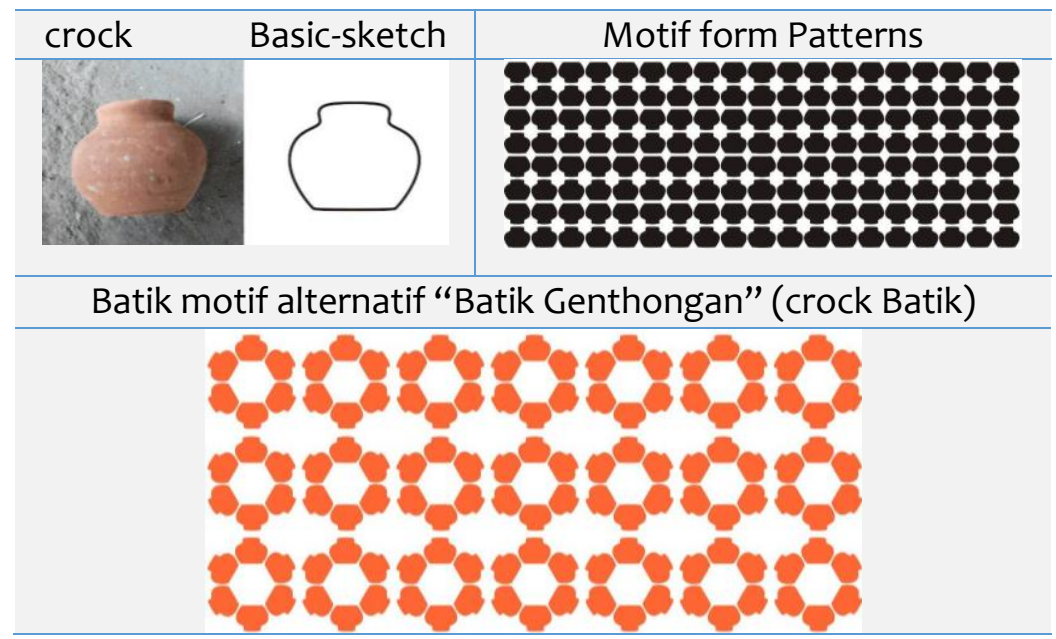

\section{Allternative development III}

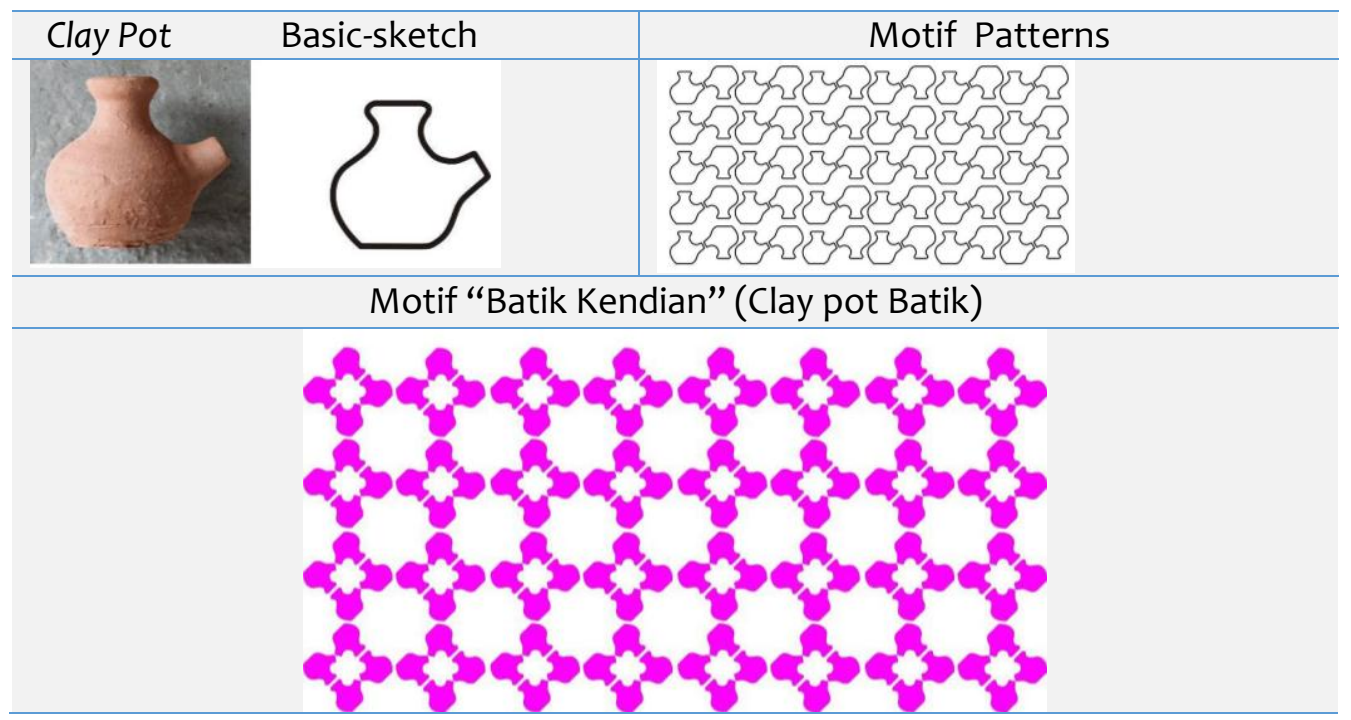




\section{Allternative development IV}

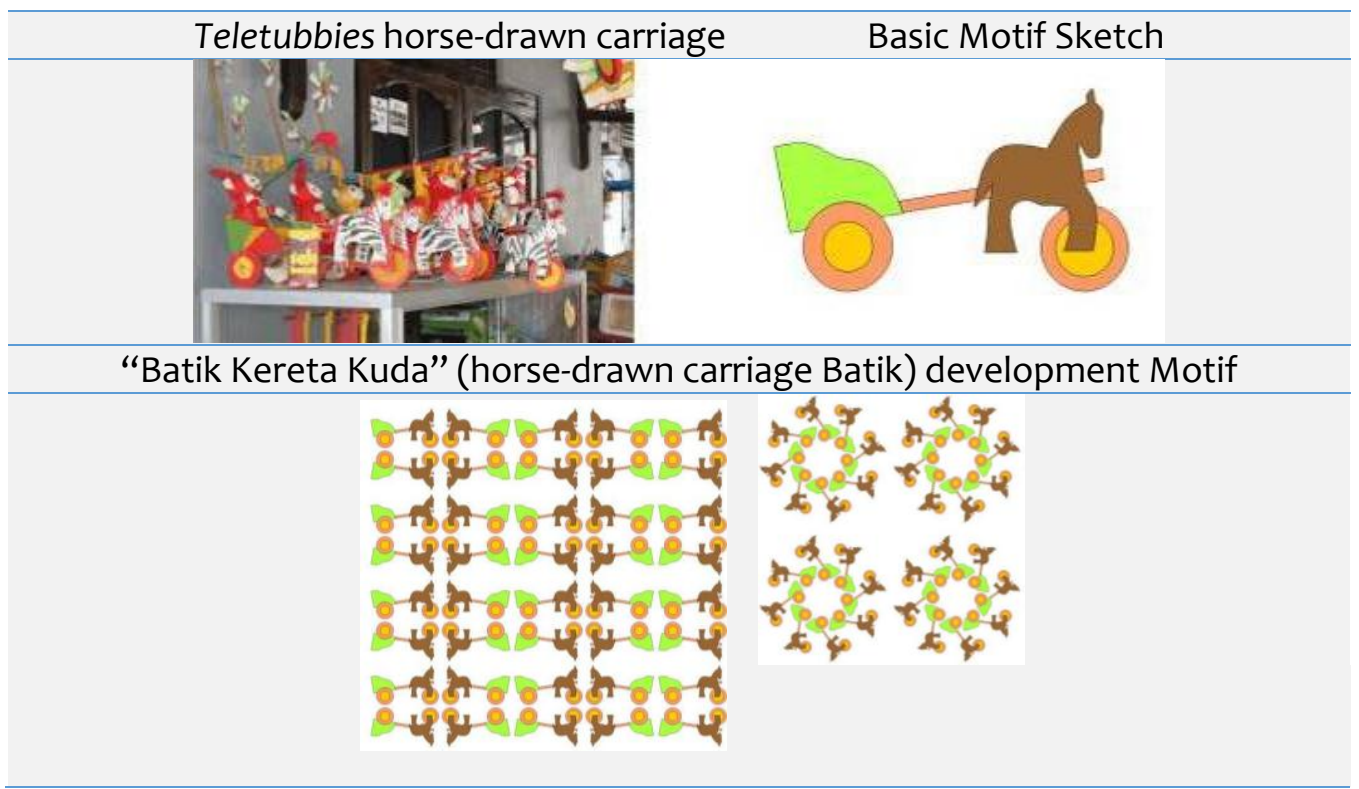

5. allternative development $\mathrm{V}$

\begin{tabular}{c|c}
\hline Baby rocking horse & basic motif sketch \\
\hline &
\end{tabular}

\section{Allternative development VI}

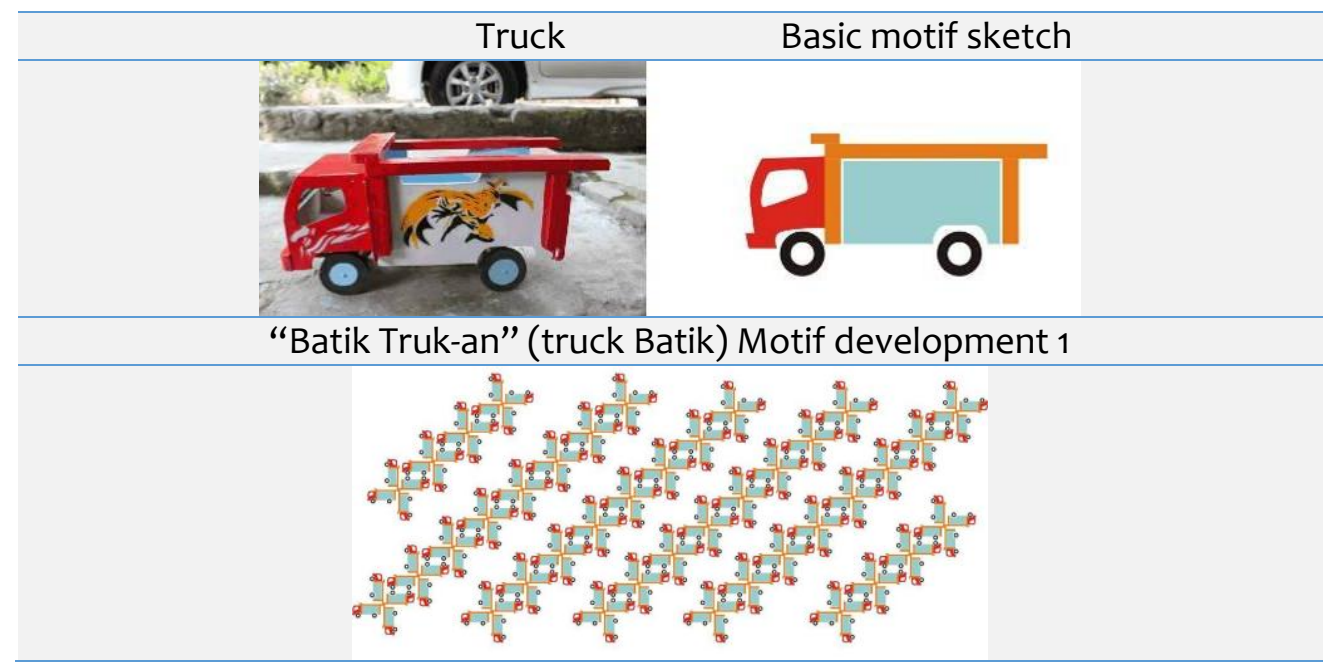




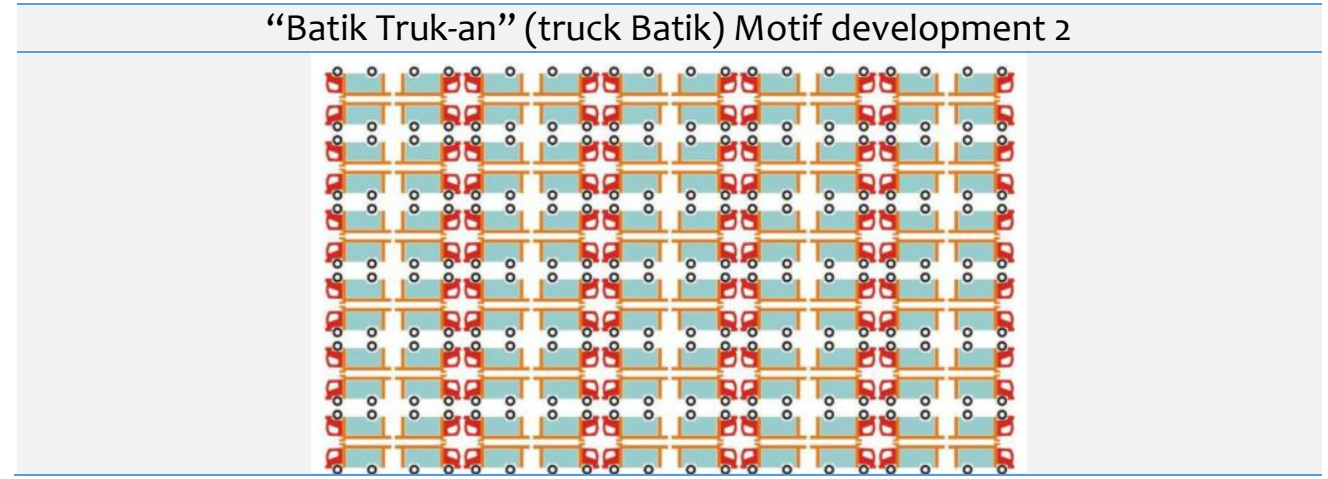

\section{Allternative development VII}

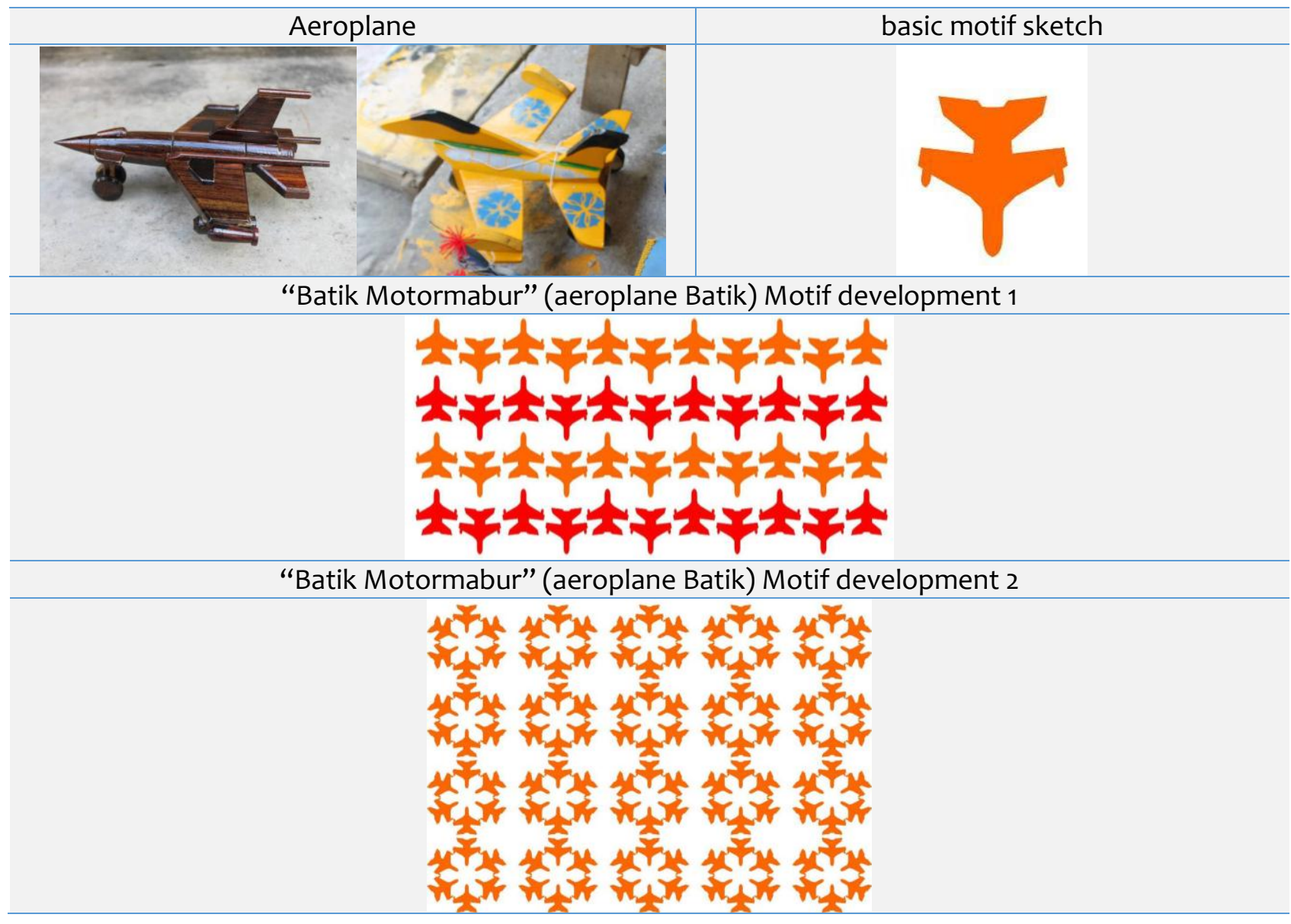

\section{Alternative development VIII}

Gangsingan basic sketch


“Batik Gangsingan” motif development 1

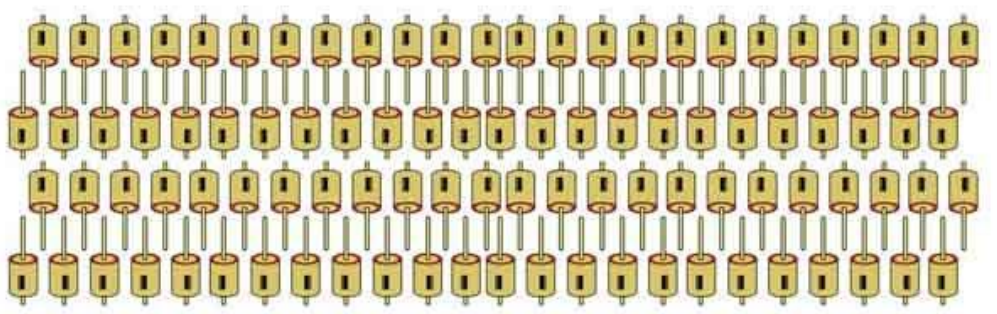

"Batik Gangsingan" motif development" 2

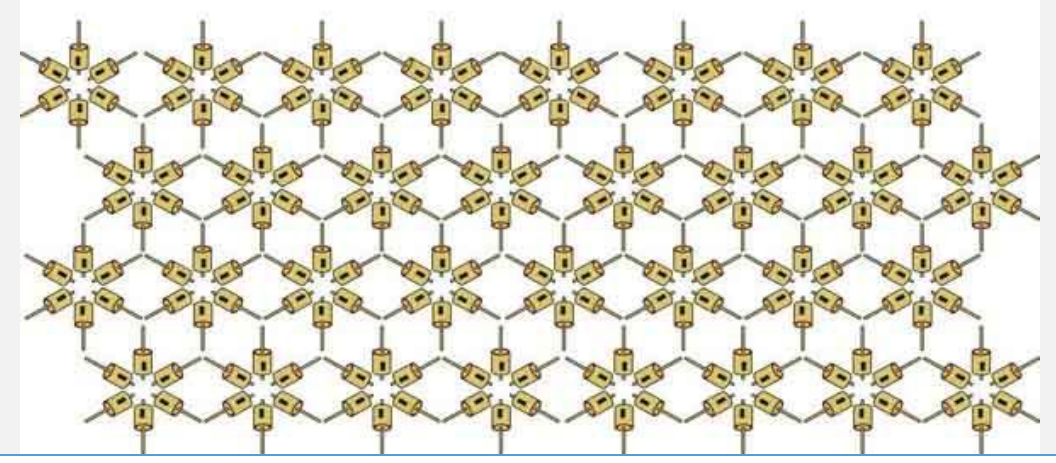

\section{Alternatif development IX}

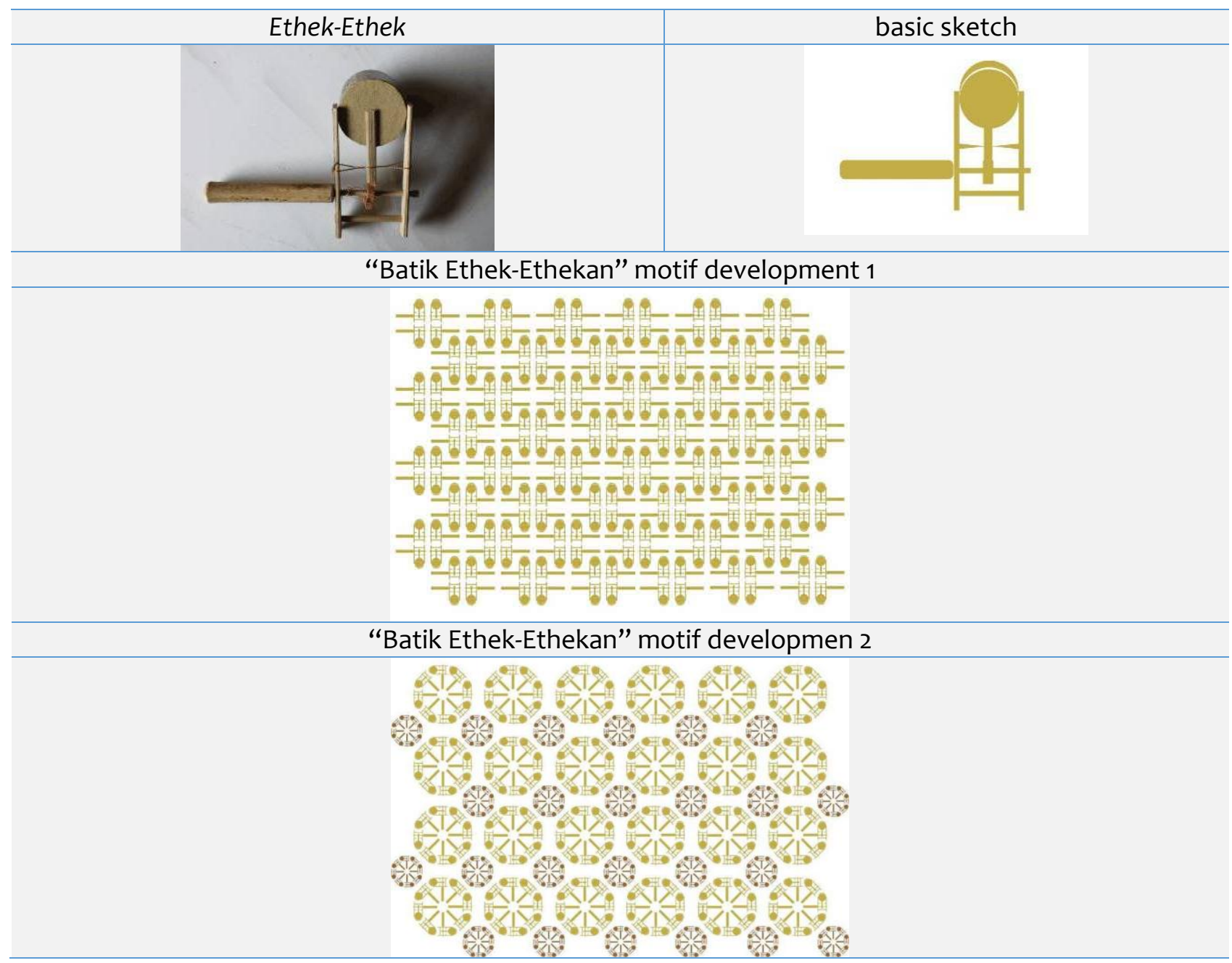


The following study designed new batik motifs on the basis of the data obtained from our research on traditional toys in the area of Central Java, Indonesia. We suggest that these batik motifs can contribute towards the promotion of the traditional toys and, also, renew the batik motifs used by the batik companies.

In Central Java, there is a variety of traditional toys that can be used as a source of ideas in the creation of these motifs, thus, contributing to the expansion of new designs and of the larger batik fashion industry. Traditional toys are increasingly excluded from children's lives in Indonesia. However, by using them in Batik design, we propose that this can lead towards their renewed popularity or it can allow them to exist in another form.

\section{References}

Agus P., Dwi. (2013). Statistik Daerah Kota Magelang. Magelang. Badan Pusat Statistik Kota Magelang. Budiarta, B., (2013). Kecamatan Mungkid Dalam Angka Tahun 2013. Magelang: Badan Pusat Statistik Kabupaten Magelang.

Bappeda M., (2013). Daerah Dalam Angka Kota Magelang Tahun 2013. Magelang. Bappeda Magelang. Dharmamulya, S., (2005). Permainan Tradisional Jawa. Yogyakarta: Kepel Press.

Gustami, S,P. (2007). Butir-Butir Mutiara Estetika Timur: Ide Dasar Penciptaan Seni Kriya Indonesia. Yogyakarta: Prasista.

Guntur, S. M. and Sugihartono. R.A., (2014). Creation the Batik Motif of mojokerto Style Based on the Majapahit's Temple Reliefs as Local Wisdom. Journal of Arts and Design Studies, 17, 8-18.

Sumarwiyanto. (2010). Hasil Sensus Penduduk 2010 Data Agregat per Kecamatan. Magelang. Badan Pusat Statistik Kota Magelang. 